\title{
Microsatellite instability, Epstein-Barr virus, mutation of type II transforming growth factor $\beta$ receptor and BAX in gastric carcinomas in Hong Kong Chinese
}

\author{
SY Leung', ST Yuen'1, LP Chung'1, KM Chu², MP Wong'1, FJ Branicki² and JCI Ho'1 \\ 1Department of Pathology and 2Department of Surgery, The University of Hong Kong, Queen Mary Hospital, Hong Kong
}

\begin{abstract}
Summary Microsatellite instability (MI), the phenotypic manifestation of mismatch repair failure, is found in a proportion of gastric carcinomas. Little is known of the links between Ml and Epstein-Barr virus (EBV) status and clinicopathological elements. Examination of genes mutated through the MI mechanism could also be expected to reveal important information on the carcinogenic pathway. Seventy-nine gastric carcinomas (61 EBV negative, 18 EBV positive) from local Hong Kong Chinese population, an intermediate-incidence area, were examined. Eight microsatellite loci, inclusive of the A10 tract of type II transforming growth factor $\beta$ receptor (T $\beta R$-II), were used to evaluate the MI status. $\mathrm{MI}$ in the BAX and insulin-like growth factor II receptor (IGF-IIR) genes were also examined. High-level MI ( $>40 \%$ unstable loci) was detected in ten cases (12.7\%) and low-level MI (1-40\% unstable loci) in three (3.8\%). High-level MI was detected in two EBV-associated cases (11\%) and the incidence was similar for the EBV-negative cases (13\%). The high-level Mls were significantly associated with intestinal-type tumours $(P=0.03)$ and a more prominent lymphoid infiltrate $(P=0.04)$. Similar associations were noted in the EBV-positive carcinomas. The highlevel Mls were more commonly located in the antrum, whereas the EBV-associated carcinomas were mostly located in body. Thirteen cardia cases were negative for both high-level MI and EBV. All patients aged below 55 were $\mathrm{Ml}$ negative $(P=0.049)$. Of the high-level Mls, $80 \%$ had mutation in T $\beta$ R-II, 40\% in BAX and $0 \%$ in IGF-IIR. Of low-level Mls, 33\% also had T $\beta$ R-II mutation. These mutations were absent in the MInegative cases. Of three lymphoepithelioma-like carcinomas, two cases were EBV positive and MI negative, one case was EBV negative but with high-level MI. In conclusion, high-level Mls were present regardless of the EBV status, and were found in a particular clinicopathological subset of gastric carcinoma patient. Inactivation of important growth regulatory genes observed in these carcinomas confirms the importance of $\mathrm{Ml}$ in carcinogenesis.
\end{abstract}

Keywords: microsatellite instability; gastric carcinoma; Hong Kong Chinese; Epstein-Barr virus; T $\beta R$ II; BAX

Microsatellite instability (MI), the phenotypic manifestation of mismatch repair failure, is detectable in a wide variety of human cancers. It is particularly seen in patients with the hereditary non-polyposis colon cancer (HNPCC) syndrome, in which the affected individual is at risk of developing carcinoma both at an early age and at a range of sites such as the colon, endometrium, urinary tract and stomach (Aaltonen et al, 1993; Marra and Boland, 1995; Lynch et al, 1996). Germline mutation in one of the DNA mismatch repair genes is responsible for a significant proportion of individuals affected by this syndrome (Fishel et al, 1993; Bronner et al, 1994; Liu et al, 1994; Nicolaides et al, 1994; Papadopoulos et al, 1994). MI has also been detected in a variable proportion of the sporadic form of cancer arising in these organs (Eshleman and Markowitz, 1995).

Although gastric cancer, worldwide, is deemed to be both the second most common malignancy and second leading cause of cancer death (Parkin et al, 1993; Pisani et al, 1993), the incidence varies markedly in different populations. The incidence of molecular genetic changes is known to vary; for example, the series of reports from high incidence areas such as Japan, Italy, Portugal

Received 27 January 1998

Revised 1 April 1998

Accepted 14 May 1998

Correspondence to: Suet Yi Leung, Department of Pathology, Queen Mary Hospital, Hong Kong and Korea show a range for MI varying from $15 \%$ to $39 \%$ (Han et al, 1993; Chong et al, 1994; Rhyu et al, 1994; Strickler et al, 1994; Lin et al, 1995; Chung et al, 1996; dos Santos et al, 1996; Ohue et al, 1996; Renault et al, 1996). Although MI was noted in a high percentage of gastric cancers with a positive family history (Akiyama et al, 1996; Keller et al, 1996; Ottini et al, 1997), germline or somatic mutations of the mismatch repetition and repair (MMR) genes were rarely reported (Akiyama et al, 1996; Keller et al, 1996). Thus, the mechanism leading to the mismatch repair failure in gastric carcinomas remains largely unknown.

The association between Epstein-Barr virus (EBV) and gastric cancer also varies among different populations, with the highest positive association occurring in Caucasian populations (Shibata and Weiss, 1992; Ott et al, 1994) and a low association seen in the Japanese (Tokunaga et al, 1993). EBV is found in more than $80 \%$ of a specific histological variant of gastric carcinoma, variably termed lymphoepithelioma-like carcinoma (LELC), medullary or gastric carcinoma with lymphoid stroma (Nakamura et al, 1994). This variant is characterized by the presence of a poorly differentiated morphology, a circumscribed border, an intense lymphoid reaction and a better prognosis (Watanabe et al, 1976). The possible relationship between EBV, MI and LELC is largely unexplored except in one study from Japan, in which all eight EBV-associated gastric cancers were negative for MI (Chong et al, 1994).

Previous data have shown that the mutator phenotype conferred by MI has a significant role in carcinogenesis, in which it targets 
specific genes that play an important role in the growth-regulatory pathway. The polyadenine tract in the type II transforming growth factor $\beta$ receptor (T $\beta R$-II) gene is one of the most commonly mutated genes in MI-positive cancers. This leads to the inactivation of an important growth-suppressive pathway (Markowitz et al, 1995; Myeroff et al, 1995; Parsons et al, 1995). Other genes harbouring polynucleotide tracts are being increasingly demonstrated to be affected, revealing the importance of MI in the carcinogenic steps.

In Hong Kong, the population is more than $90 \%$ southern Chinese and the annual incidence of gastric cancer is 13.2, an intermediate incidence area (Hong Kong Cancer Registry, 1996). This study examines the incidence of MI in gastric cancer in Hong Kong Chinese when correlated with various clinicopathological parameters. The relationship of MI with EBV, mutation of the polynucleotide tract of T $\beta$ R-II, BAX and insulin-like growth factor II receptor (IGF-IIR) were particularly examined, in an attempt to further elucidate the role of $\mathrm{MI}$ in carcinogenesis.

\section{MATERIALS AND METHODS}

\section{Materials}

Seventy-nine cases of gastric carcinoma from Hong Kong Chinese were studied, with the series consisting of 18 cases of EBV-associated and $61 \mathrm{EBV}$-negative gastric carcinomas. The EBV-associated cases were derived from the screening of 290 non-consecutive gastric carcinomas from 1986 to 1997 using in situ hybridization to detect EBV-encoded RNAs (EBER), as described previously (Yuen et al, 1994). The EBV-negative cases were from gastrectomy specimens performed in the period 1993-97 for whom frozen blocks were still available. Paired tumour and normal tissue blocks were selected. The normal tissue was dissected away as much as possible in the tumour blocks, and cryostat or paraffin sections were cut and examined to confirm the tumour cell percentage. Only those tumour blocks containing more than $30 \%$ tumour cells were selected. The normal blocks were similarly examined to ensure the absence of tumour cell contamination. Sections were cut, deparaffinized as needed and suspended in proteinase $\mathrm{K}$ buffer. DNA was purified using a standard proteinase $\mathrm{K}$ digestion, phenol-chloroform extraction method.

\section{Methods}

Eight loci were used to evaluate the MI status. These included five dinucleotide repeats (Tp53, D18S58, D18S57, D2S123, D5S346) and three mononucleotide repeats of polyadenine tracts (BAT26, BAT40 and BAT-RII). Tp53, D18S58, D18S57, D2S123 and D5S346 were purchased from Research Genetics (Huntsville, AL, USA). BAT26 and BAT40 were synthesized according to the sequence published previously (Liu et al, 1996). For D2S123 and D18S58, additional sets of primers synthesized according to the published sequence (Liu et al, 1996) were also used. The BAT-RII, synthesized according to Myeroff et al (1995), amplify a 73-bp region of the T $\beta R$-II gene. These span nucleotides $665-737$, which contain a polyadenine tract. In $87 \%$ of cases, seven to eight loci were analysed. In the remaining $13 \%$, at least five of these eight loci were analysed, including both dinucleotide and polyadenine repeats.

The primer sequences for BAX were the same as those described by Rampino et al (1997), and amplified a segment containing eight consecutive deoxyguanosines spanning codons 38-41. The primer for IGF-IIR amplified a segment spanning nucleotides 4030-4140, which contained an eight-deoxyguanine repeat (Souza et al, 1996). All cases with microsatellite instability were analysed for frameshift mutation in the BAX and IGF-IIR gene. An additional 48 MI-negative cases were also analysed for BAX mutation.

The polymerase chain reaction (PCR) was performed in a $10-\mu \mathrm{l}$ reaction solution containing $50 \mathrm{ng}$ of DNA, $10 \mathrm{~mm}$ Tris $(\mathrm{pH} 8.3)$, $50 \mathrm{~mm}$ potassium chloride, $2-3 \mathrm{mM} \mathrm{Mg}^{2+}, 200 \mu \mathrm{M} \mathrm{dNTP}, 1 \mu \mathrm{Ci}$ of $\left[\alpha-{ }^{32} \mathrm{P}\right] \mathrm{dCTP}, 0.2-1 \mu \mathrm{M}$ of each primers and $0.1 \mathrm{U}$ Taq polymerase. Hot-start reaction was performed by preheating the mixture in the thermocycler at $95^{\circ} \mathrm{C}$ for $5 \mathrm{~min}$, then $80^{\circ} \mathrm{C}$ before adding the Taq polymerase. An initial denaturation step of $95^{\circ} \mathrm{C}$ for $5 \mathrm{~min}$ and $25-40$ cycles including $95^{\circ} \mathrm{C}$ for $45 \mathrm{~s}(1 \mathrm{~min}), 1 \mathrm{~min}$ (1.5 min) in $52-64^{\circ} \mathrm{C}$ annealing temperature according to the specific primers, and $72^{\circ} \mathrm{C}$ for $1 \mathrm{~min}(2 \mathrm{~min})$ in frozen DNA (paraffin DNA) was performed, followed by a final extension of 5 min at $72^{\circ} \mathrm{C}$.

The PCR products were diluted by loading buffer, heated at $95^{\circ} \mathrm{C}$ for $5 \mathrm{~min}$ and loaded onto $7 \%$ vertical polyacrylamide gel. After electrophoresis, the gels were fixed and dried and exposed to radiographic film for between $12 \mathrm{~h}$ and 7 days. The band patterns between the tumour and non-tumour tissue were compared and scored by two independent investigators. All cases with alteration of band sizes in the tumour tissue compared with normal were repeated once. The number of loci showing microsatellite instability were recorded in each case. Cases with $>40 \%$ unstable loci, including both types of repeats, were classified as high-level MIs. Cases with $1-40 \%$ unstable loci were classified as low-level MIs.

\section{RESULTS}

Microsatellite instability was detected in 13 cases $(16.5 \%)$; including ten (12.7\%) high-level MIs and three (3.8\%) low-level MIs (Table 1). The high-level MIs tended to have lots of unstable loci involving both dinucleotide and mononucleotide repeats, whereas the low-level MIs tended to affect the mononucleotide repeats only. Although two of the high-level MIs were also EBV associated, the incidence of high-level MI was similar for the EBV-positive (11\%) and EBV-negative cases (13\%). Of the ten high-level MIs, eight $(80 \%)$ had frameshift mutation in the A10 tract of T $\beta$ R-II and four (40\%) had frameshift mutation in the G8 tract of BAX gene. All cases with BAX mutation also had mutation of the T $\beta$ R-II gene. One of the three (33\%) low-level MIs had mutation of the A10 tract of T $\beta$ R-II. No mutation of the IGF-IIR gene was detected in any of the MI cases. Mutation of T $\beta$ R-II and BAX was not detected in any of the MI-negative cases. Representative results of the microsatellite analysis are shown in Figures 1 and 2.

The relationship between MI and EBV status and clinicopathological parameters is shown in Tables 2 and 3. All the high-level MIs were of intestinal type, which differs significantly from the low-level and negative MIs (Fisher exact test, $P=0.03$ ). The high-level MIs also had a significantly more prominent lymphoid infiltrate (Fisher exact test, $P=0.04$ ). Three cases had the morphological characteristic of LELC, two were EBV positive and MI negative, whereas one was EBV negative but with highlevel MI. The EBV-associated cases were most commonly located in the gastric body (chi-squared test, $P<0.00001$ ), whereas the high-level MIs were mostly located in the antrum but did not reach 
Table 1 Clinicopathological features, mutation of the TßR-II, BAX and IGF-IIR genes in microsatellite instability (MI)-positive gastric carcinomas

\begin{tabular}{|c|c|c|c|c|c|c|c|c|c|c|c|c|c|}
\hline Patient & 1 & 2 & 3 & 4 & 5 & 6 & 7 & 8 & 9 & 10 & 11 & 12 & 13 \\
\hline Sex & $\mathrm{F}$ & M & $\mathrm{F}$ & M & $\mathrm{F}$ & M & M & M & $\mathrm{F}$ & M & $\mathrm{F}$ & $\mathrm{F}$ & M \\
\hline Age & 77 & 59 & 77 & 78 & 65 & 66 & 63 & 57 & 79 & 79 & 79 & 73 & 55 \\
\hline Tumour site & C & C & A & B & B & A & A & A & A & B & A & A & A \\
\hline Laurens' type & 1 & 1 & D & 1 & 1 & 1 & 1 & 1 & 1 & $\mathrm{f}^{\mathrm{b}}$ & 1 & 1 & 1 \\
\hline Lymphoid infiltrate & 1 & 0 & 0 & 2 & 2 & 0 & 2 & 2 & 1 & 3 & 3 & 0 & 2 \\
\hline EBV status & 0 & 0 & 0 & 1 & 1 & 0 & 0 & 0 & 0 & 0 & 0 & 0 & 0 \\
\hline Tp53 & 0 & 0 & 0 & 0 & 1 & 1 & 1 & 1 & 1 & 1 & 1 & 1 & 1 \\
\hline D18S58 & 0 & 0 & 0 & ND & 1 & 1 & 1 & 1 & 1 & 0 & 1 & 1 & 1 \\
\hline D18S57 & 0 & ND & 0 & ND & ND & 1 & 0 & 0 & 0 & ND & ND & ND & 1 \\
\hline D2S123 & 0 & 0 & 0 & 1 & 1 & 0 & 0 & 1 & 0 & 1 & 1 & 1 & 1 \\
\hline D5S346 & 0 & 0 & 0 & 0 & 0 & 1 & 1 & 0 & 1 & 1 & ND & 1 & 1 \\
\hline ВАT26 & 0 & 0 & 0 & 0 & 0 & 0 & 1 & 1 & 1 & 1 & 1 & 1 & 1 \\
\hline BAT40 & 1 & 1 & 1 & 1 & 1 & 1 & 1 & 1 & 1 & 1 & 1 & 1 & 1 \\
\hline BAT-RII & 0 & 0 & 1 & 1 & 0 & 0 & 1 & 1 & 1 & 1 & 1 & 1 & 1 \\
\hline No. of Ml/locia & $1 / 8$ & $1 / 7$ & $2 / 8$ & $3 / 6$ & $4 / 7$ & $5 / 8$ & $6 / 8$ & $6 / 8$ & $6 / 8$ & $6 / 7$ & $6 / 6$ & $7 / 7$ & $8 / 8$ \\
\hline$\%$ Unstable loci & 13 & 14 & 25 & 50 & 57 & 63 & 75 & 75 & 75 & 86 & 100 & 100 & 100 \\
\hline BAX (G8 tract) & 0 & 0 & 0 & 1 & 0 & 0 & 0 & 1 & 1 & 0 & 0 & 1 & 0 \\
\hline IGF-IIR (G8 tract) & 0 & 0 & 0 & 0 & 0 & 0 & 0 & 0 & 0 & 0 & 0 & 0 & 0 \\
\hline
\end{tabular}

Tumour site: C, cardia; B, body; A, antrum; Laurens' tumour type: I, intestinal; D, diffuse; Lymphoid infiltrate: 0, minimal; 1, mild; 2, moderate; 3 , intense; EBV status; 0 , negative; 1 , positive; microsatellite instability; 0 , negative; 1 , positive; ND, not determined; ainclusive of BAT-RII (A10 tract of T $\beta$ RII); bthis is a case of lymphoepithelioma-like carcinoma.

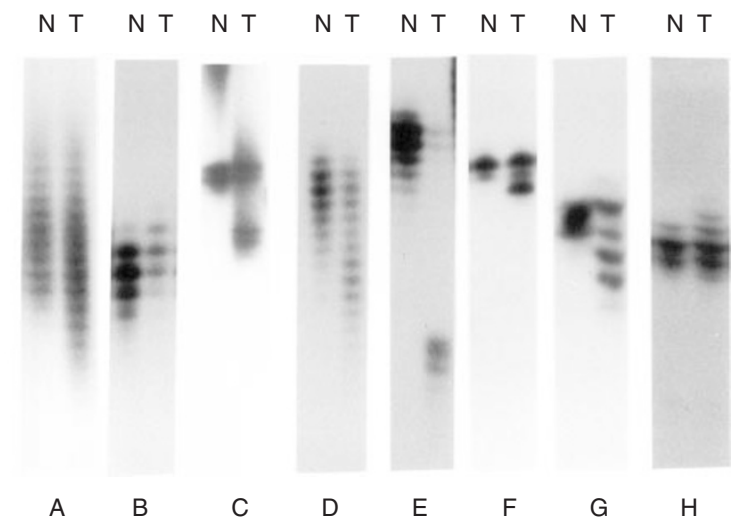

Figure 1 Microsatellite alteration at various loci in gastric carcinoma. (A) Tp53; (B) D2S123; (C) D18S58; (D) BAT40; (E) BAT26; (F) BAT-RII; (G) D18S57; (H) D5S346. N, normal tissue; T, tumour tissue

statistical significance. There were 13 cases from the cardia and all were negative for high-level MI and EBV. There was no significant association for high-level MIs or EBV status with sex, tumour differentiation, tumour depth of invasion or lymph node metastasis.

Both high-level and low-level MIs were found in patients aged 55 or above. None of the 15 patients aged below 55 showed MI. Although comparison of high-level MIs compared with low/negative MIs did not quite reach statistical significance (Fisher exact test, $P=0.1$ ), the difference between negative and low-/high-level MIs was significant (chi-squared test, $P=0.049$ ).

\section{DISCUSSION}

This study detected the presence of high-level MI in $12.7 \%$ of gastric carcinomas in Hong Kong Chinese. Though the overall incidence of $\mathrm{MI}$ in our series is low $(16.5 \%)$, the incidence of highlevel MI is either similar (Han et al, 1993; Chong et al, 1994; Strickler et al, 1994; Ohue et al, 1996; Ottini et al, 1997) or only

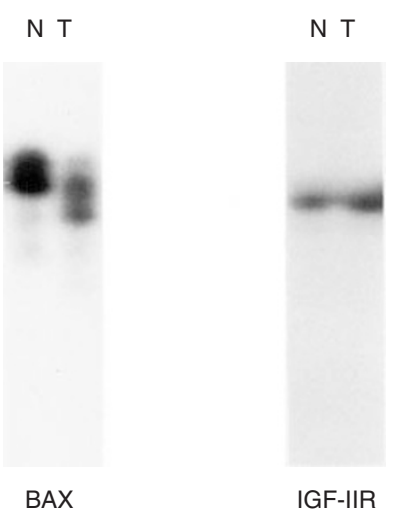

Figure 2 Frameshift mutation is noted in the BAX gene but absent in the IGF-IIR gene. N, normal tissue; T, tumour tissue

slightly lower (Rhyu et al, 1994; Chung et al, 1996; dos Santos et al, 1996) when compared with many large series from high-incidence areas. Although the low-level MI cases may simply represent an inherent instability of repeat sequences in cancer tissue, the high-level MI cases are highly suggestive of defects in the DNA mismatch repair systems. In fact, a criteria of more than $40 \%$ unstable loci were advocated by some groups to qualify a case as MI (Bocker et al, 1997; Dietmaier et al, 1997). Our study has identified a specific clinicopathological profile in patients with high-level MIs: they are all elderly patients, the tumours are of intestinal type and show a significantly more intense lymphoid infiltrate. Also, location in the antrum is more common.

Our results confirm the previous observations of dos Santos et al (1996), who demonstrated more prominent lymphoid infiltrate in gastric carcinoma when there was a high level of MI. This invites comparison with those MI-positive colorectal carcinomas in which Crohn's disease-like lymphoid reaction is also more commonly seen (Kim et al, 1994). Our study included three LELC cases; two were $\mathrm{EBV}$ associated with negative $\mathrm{MI}$, and one was EBV 
Table 2 Microsatellite instability and clinicopathological features in 79 gastric carcinomas

\begin{tabular}{|c|c|c|c|c|c|}
\hline & $\begin{array}{l}\text { MI-negative } \\
\text { (0\% locus) }\end{array}$ & $\begin{array}{l}\text { Low-level MI } \\
\text { (1-40\% loci) }\end{array}$ & $\begin{array}{l}\text { High-level MI } \\
\text { (>40\% loci) }\end{array}$ & Total & $P$-value ${ }^{a}$ \\
\hline \multicolumn{6}{|l|}{ Sex } \\
\hline M & $49(14)$ & 1 & $6(1)$ & 56 & \\
\hline $\mathrm{F}$ & $17(2)$ & 2 & $4(1)$ & 23 & \\
\hline \multicolumn{6}{|l|}{ Age groups (years) } \\
\hline$<45$ & $12(4)$ & 0 & 0 & 12 & $P=0.1^{\mathrm{b}}$ \\
\hline $45-54$ & 3 & 0 & 0 & 3 & High vs low/negative MI, \\
\hline $55-64$ & $20(6)$ & 1 & 3 & 24 & $<55$ vs $55+$ \\
\hline $65+$ & $31(6)$ & 2 & $7(2)$ & 40 & \\
\hline \multicolumn{6}{|l|}{ Differentiation } \\
\hline Moderate & $26(5)$ & 2 & 5 & 33 & \\
\hline Poor & $40(11)$ & 1 & $5(2)$ & 46 & \\
\hline \multicolumn{6}{|l|}{ Tumour type } \\
\hline Intestinal & $45\left(14^{c}\right)$ & 2 & $10^{d}(2)$ & 57 & $P=0.03$ \\
\hline Diffuse & 13 & 1 & 0 & 14 & High vs low/negative MI, \\
\hline Mixed & $8(2)$ & 0 & 0 & 8 & Intestinal vs diffuse/mixed \\
\hline \multicolumn{6}{|l|}{ Tumour site } \\
\hline Cardia & 11 & 2 & 0 & 13 & \\
\hline Body & $21(12)$ & 0 & $3(2)$ & 24 & \\
\hline Antrum & $34(4)$ & 1 & 7 & 42 & \\
\hline \multicolumn{6}{|l|}{ Lymphoid infiltrate } \\
\hline Minimal/mild & $42(5)$ & 3 & 3 & 48 & $P=0.04$ \\
\hline Moderate/severe & $24(11)$ & 0 & $7(2)$ & 31 & High vs low/negative MI \\
\hline \multicolumn{6}{|l|}{ Tumour level } \\
\hline Submucosa & $2(1)$ & 0 & 0 & 2 & \\
\hline Muscle & $7(1)$ & 1 & 4 & 12 & \\
\hline Serosa & $57(14)$ & 2 & $6(2)$ & 65 & \\
\hline \multicolumn{6}{|l|}{ Lymph node } \\
\hline Negative & $13(2)$ & 0 & 2 & 15 & \\
\hline Positive & $53(14)$ & 3 & $8(2)$ & 64 & \\
\hline
\end{tabular}

aFisher exact test, one tail; bMI negative vs low-/high-level MI, $<55$ vs 55+, $P=0.049$; numbers in parentheses equal to number of EBV-positive cases; cinclusive of two cases of LELC; dinclusive of one case of LELC.

negative but showed high-level MI. There is also a reported series of 13 colonic medullary carcinomas which were all EBV negative but MI positive (Ruschoff et al, 1997). Thus, it appears that MI may contribute to a subset of carcinoma with the morphological features of LELC/medullary carcinoma. The lymphoid reaction in LELC with MI may be triggered by more frequent genetic errors resulting in formation of mutated immunogenic proteins, or, in the EBV-associated cases, by expression of certain viral antigens in the carcinoma cells.

The association of high-level MI with intestinal type tumour and antral location correlate well with the results of Chung et al (1996) and Ottini et al (1997). Although EBV-associated cases were also more commonly seen in intestinal type tumours with intense lymphoid infiltrate, these were mostly located in the gastric body. In this series, none of the carcinoma in the cardia were associated with EBV or high-level MI. This poses an interesting question concerning regional susceptibility of the stomach to different carcinogenic pathways.

The mutator phenotype conferred by MI plays an important role in carcinogenesis. In previous series, insertion/deletions in the polyadenine tract of TGF- $\beta$ RII genes has been detected in more than $70 \%$ of gastric carcinomas with MI (Myeroff et al, 1995; Chung et al, 1996; Yamamoto et al, 1997). We also found mutations of T $\beta R-I I$ in $80 \%$ of gastric carcinomas with high-level MI, one of which was seen in an EBV-associated case. It is interesting to note that in $70 \%$ of the tumours with high-level MIs, there is a moderate to intense lymphoid infiltrate. Now, as TGF- $\beta$ is a potent growth inhibitor of epithelial cells as well as a potent immunosuppressive cytokine (Kehrl, 1991; Wojtowicz Praga, 1997), the cancer cells with mutated T $\beta$ R-II may be both released from the growth-inhibitory effect of TGF- $\beta$ and yet benefit from its immunosuppressive effect.

The BAX gene is an antagonist of Bcl-2, and promotes apoptosis. Inactivation of this gene due to frameshift mutation in the GI tract was first reported to occur in more than $50 \%$ of MI-positive colorectal carcinomas (Rampino et al, 1997). Two subsequent series reported a total of 20 BAX frameshift mutations in $31 \mathrm{MI}-$ positive gastric carcinomas (65\%) (Chung et al, 1997; Yamamoto et al, 1997). In the current series, we found BAX mutation in $40 \%$ of the high-level MIs. None of the low-level MIs or MI-negative cases showed this type of frameshift mutation. Moreover, all cases with BAX mutation also showed mutation in T $\beta$ R-II. This supports the notion that, although MI causes mutation in a random fashion, only specific genes involved in control of cell cycle or apoptosis were selected for in the carcinogenic process. Interestingly, none of the MI-positive cases in our series showed IGF-IIR mutation. There have only been a few reports on mutation of this gene in gastric cancers but in most series the incidence of mutation is low, ranging from $8 \%$ to $33 \%$ (Souza et al, 1996; Chung et al, 1997; Ouyang et al, 1997; Yamamoto et al, 1997). 
Table 3 EBV and the clinicopathological features in 79 gastric carcinomas

\begin{tabular}{|c|c|c|c|c|}
\hline & EBV-negative & EBV positive & Total & $P$-value ${ }^{a}$ \\
\hline \multicolumn{5}{|l|}{ Sex } \\
\hline M & $41(5)$ & $15(1)$ & 56 & \\
\hline $\mathrm{F}$ & $20(3)$ & $3(1)$ & 23 & \\
\hline \multicolumn{5}{|l|}{ Age groups (years) } \\
\hline$<45$ & 8 & 4 & 12 & \\
\hline $45-54$ & 3 & 0 & 3 & \\
\hline $55-64$ & $18(3)$ & 6 & 24 & \\
\hline $65+$ & $32(5)$ & $8(2)$ & 40 & \\
\hline \multicolumn{5}{|l|}{ Differentiation } \\
\hline Moderate & $28(5)$ & 5 & 33 & \\
\hline Poor & $33(3)$ & $13(2)$ & 46 & \\
\hline \multicolumn{5}{|l|}{ Tumour type } \\
\hline Intestinal & $41\left(8^{b}\right)$ & $16^{c}(2)$ & 57 & $P=0.07$ \\
\hline Diffuse & 14 & 0 & 14 & Intestinal vs diffuse/mixed \\
\hline Mixed & 6 & 2 & 8 & \\
\hline \multicolumn{5}{|l|}{ Tumour site } \\
\hline Cardia & 13 & 0 & 13 & $P<0.00001$ \\
\hline Body & $10(1)$ & $14(2)$ & 24 & \\
\hline Antrum & $38(7)$ & 4 & 42 & \\
\hline \multicolumn{5}{|l|}{ Lymphoid infiltrate } \\
\hline Minimal/mild & $43(3)$ & 5 & 48 & $P=0.001$ \\
\hline Moderate/severe & $18(5)$ & $13(2)$ & 31 & \\
\hline \multicolumn{5}{|l|}{ Tumour level } \\
\hline Submucosa & 1 & 1 & 2 & \\
\hline Muscle & $11(4)$ & 1 & 12 & \\
\hline Serosa & $49(4)$ & $16(2)$ & 65 & \\
\hline \multicolumn{5}{|l|}{ Lymph node } \\
\hline Negative & $13(2)$ & 2 & 15 & \\
\hline Positive & $48(6)$ & $16(2)$ & 64 & \\
\hline
\end{tabular}

${ }^{a}$ Chi-squared test; numbers in parentheses equal to number of high-level MI cases; binclusive of one case of LELC; cinclusive of two cases of LELC.

Also, tumours tend to be positive for either T $\beta$ R-II or IGF-IIR mutation, but not both (Souza et al, 1996). This can be explained by the fact that IGF-IIR is required for the activation of the TGF$\beta 1$ complex from its latent form so that they may constitute serial points in the same carcinogenic pathway (Souza et al, 1996). Because most of the high-level MIs are positive for T $\beta$ R-II mutation in our series, the absence of IGF-IIR mutation is consistent with the hypothesis. In summary, inactivation of T $\beta$ R-II appears to be the most common and important pathway targeted by MI in gastric carcinomas, followed by BAX gene, whereas mutation of IGF-IIR is relatively uncommon.

We found high-level MI in both EBV-negative as well as EBVpositive gastric carcinomas. This is in contrast to a previous study by Chong et al (1994), who found no MI in eight EBV-associated gastric carcinomas. Whether MI is present in other EBV-associated carcinomas is not known. The possibility that MI is caused by the human immunodeficiency virus (HIV) has been raised by a group of investigators who detected a high incidence of $\mathrm{MI}$ in B-cell non-Hodgkin's lymphoma and in Kaposi sarcoma developing in patients with the acquired immunodeficiency syndrome (AIDS) (Bedi et al, 1995). Because a high proportion of B-cell non-Hodgkin's lymphoma in AIDS patients are associated with EBV (Shibata et al, 1993; Hamilton Dutoit and Pallesen, 1994; Anagnostopoulos and Hummel, 1996), and human herpesvirus 8 is present in Kaposi sarcoma (Schalling et al, 1995), it would be most useful to determine whether the MI observed in these tumours was related to the HIV or the other two herpes viruses.

Although there is a high incidence of MI in young colorectal cancer patients both in Hong Kong (Chan et al, 1997) and elsewhere (Liu et al, 1995), this does not seem to be so in gastric cancer. None of the 12 gastric cancer patients aged below 45 in our series showed MI, and all the MI cases were aged 55 or above. Thus, although gastric cancer is within the spectrum of HNPCCrelated tumours, it cannot account for the young gastric cancer in our population.

In summary, MI may constitute an important carcinogenic pathway in a specific clinicopathological subgroup of gastric carcinoma through inactivation of specific growth regulatory genes. The mechanism leading to MI in these sporadic gastric carcinomas is an area for further studies.

\section{ACKNOWLEDGEMENTS}

We thank Miss Annie SY Chan and Mr Samson WC Shum for the excellent technical assistance, Dr Robert J Collins for editing the manuscript. Part of this work constitutes the M.D. thesis of Dr SY Leung. This work is supported by the Michael and Betty Kadoorie Foundation Cancer Research Genetics Fund. 


\section{REFERENCES}

Aaltonen LA, Peltomaki P, Leach FS, Sistonen P, Pylkkanen L, Mecklin JP, Jarvinen H, Powell SM, Jen J, Hamilton SR, Petersen GM, Kinzler KW, Vogelstein B and De La Chapelle A (1993) Clues to the pathogenesis of familial colorectal cancer. Science 260: 812-816

Akiyama Y, Nakasaki H, Nihei Z, Iwama T, Nomizu T, Utsunomiya J and Yuasa Y (1996) Frequent microsatellite instabilities and analyses of the related genes in familial gastric cancers. Jpn J Cancer Res 87: 595-601

Anagnostopoulos I and Hummel M (1996) Epstein-Barr virus in tumours. Histopathology 29: 297-315

Bedi GC, Westra WH, Farzadegan H, Pitha PM and Sidransky D (1995) Microsatellite instability in primary neoplasms from HIV + patients. Nature Med 1: 65-68

Bocker T, Diermann J, Friedl W, Gebert J, Holinski Feder E, Karner H, Von Knebel Doeberitz M, Koelble K, Moeslein G, Schackert HK, Wirtz HC, Fishel R and Ruschoff J (1997) Microsatellite instability analysis: a multicenter study for reliability and quality control. Cancer Res 57: 4739-4743

Bronner CE, Baker SM, Morrison PT, Warren G, Smith LG, Lescoe MK, Kane M, Earabino C, Lipford J, Lindblom A, Tannergard P, Bollag RJ, Godwin AR, Ward DC, Nordenskjold M, Fishel R, Kolodner R and Liskay RM (1994) Mutation in the DNA mismatch repair gene homologue hMLH1 is associated with hereditary non-polyposis colon cancer. Nature $\mathbf{3 6 8}$ : $258-261$

Chan TL, Yuen ST, Chung LP, Ho J, Leung SY, Chan AS and Chan LC (1997) Replication errors (RER) and mismatch repair (MMR) gene mutations in young colorectal carcinoma patients in Hong Kong Chinese. In Proceedings of Keystone Symposium on Molecular and Cellular Biology - Genetics of Human Cancer: Pathogenesis and Diagnosis, Colorado, p. 9

Chong JM, Fukayama M, Hayashi Y, Takizawa T, Koike M, Konishi M, Kikuchi Yanoshita R and Miyaki M (1994) Microsatellite instability in the progression of gastric carcinoma. Cancer Res 54: 4595-4597

Chung YJ, Song JM, Lee JY, Jung YT, Seo EJ, Choi SW and Rhyu MG (1996) Microsatellite instability-associated mutations associate preferentially with the intestinal type of primary gastric carcinomas in a high-risk population. Cancer Res 56: 4662-4665

Chung YJ, Park SW, Song JM, Lee KY, Seo EJ, Choi SW and Rhyu MG (1997) Evidence of genetic progression in human gastric carcinomas with microsatellite instability. Oncogene 15: 1719-1726

Dietmaier W, Wallinger S, Bocker T, Kullmann F, Fishel R and Ruschoff J (1997) Diagnostic microsatellite instability: definition and correlation with mismatch repair protein expression. Cancer Res 57: 4749-4756

Dos Santos NR, Seruca R, Constancia M, Seixas M and Sobrinho Simoes M (1996) Microsatellite instability at multiple loci in gastric carcinoma: clinicopathologic implications and prognosis. Gastroenterology 110: 38-44

Eshleman JR and Markowitz SD (1995) Microsatellite instability in inherited and sporadic neoplasms. Curr Opinion Oncol 7: 83-89

Fishel R, Lescoe MK, Rao MR, Copeland NG, Jenkins NA, Garber J, Kane M and Kolodner R (1993) The human mutator gene homolog MSH2 and its association with hereditary nonpolyposis colon cancer. Cell 75: 1027-1038

Hamilton Dutoit SJ and Pallesen G (1994) Detection of Epstein-Barr virus small RNAs in routine paraffin sections using non-isotopic RNA/RNA in situ hybridization. Histopathology 25: 101-111

Han HJ, Yanagisawa A, Kato Y, Park JG and Nakamura Y (1993) Genetic instability in pancreatic cancer and poorly differentiated type of gastric cancer. Cancer Res 53: 5087-5089

Hong Kong Cancer Registry (1996) Cancer Incidence and Mortality in Hong Kong 1992, p. 4. Hospital Authority: Hong Kong

Kehrl JH (1991) Transforming growth factor-beta: an important mediator of immunoregulation. Int J Cell Cloning 9: 438-450

Keller G, Grimm V, Vogelsang H, Bischoff P, Mueller J, Siewert JR and Hofler H (1996) Analysis for microsatellite instability and mutations of the DNA mismatch repair gene hMLH1 in familial gastric cancer. Int J Cancer $\mathbf{6 8}$ $571-576$

Kim H, Jen J, Vogelstein B and Hamilton SR (1994) Clinical and pathological characteristics of sporadic colorectal carcinomas with DNA replication errors in microsatellite sequences. Am J Pathol 145: 148-156

Lin JT, Wu MS, Shun CT, Lee WJ, Wang JT, Wang TH and Sheu JC (1995) Microsatellite instability in gastric carcinoma with special references to histopathology and cancer stages. Eur J Cancer 31A: 1879-1882

Liu B, Parsons RE, Hamilton SR, Petersen GM, Lynch HT, Watson P, Markowitz S, Willson JK, Green J, De La Chapelle A, Kinzler KW and Vogelstein B (1994) hMSH2 mutations in hereditary nonpolyposis colorectal cancer kindreds. Cancer Res 54: 4590-4594
Liu B, Farrington SM, Petersen GM, Hamilton SR, Parsons R, Papadopoulos N, Fujiwara T, Jen J, Kinzler KW, Wyllie AH, Vogelstein B and Dunlop MG (1995) Genetic instability occurs in the majority of young patients with colorectal cancer. Nature Med 1: 348-352

Liu B, Parsons R, Papadopoulos N, Nicolaides NC, Lynch HT, Watson P, Jass JR, Dunlop M, Wyllie A, Peltomaki P, De La Chapelle A, Hamilton SR, Vogelstein B and Kinzler KW (1996) Analysis of mismatch repair genes in hereditary non-polyposis colorectal cancer patients. Nature Med 2: 169-174

Lynch HT, Smyrk T and Lynch JF (1996) Overview of natural history, pathology, molecular genetics and management of HNPCC (Lynch syndrome). Int $J$ Cancer 69: 38-43

Markowitz S, Wang J, Myeroff L, Parsons R, Sun L, Lutterbaugh J, Fan RS, Zborowska E, Kinzler KW, Vogelstein B, Brattain M and Willson JK (1995) Inactivation of the type II TGF-beta receptor in colon cancer cells with microsatellite instability. Science 268: 1336-1338

Marra G and Boland CR (1995) Hereditary nonpolyposis colorectal cancer: the syndrome, the genes, and historical perspectives. J Natl Cancer Inst 87: $1114-1125$

Myeroff LL, Parsons R, Kim SJ, Hedrick L, Cho KR, Orth K, Mathis M, Kinzler KW, Lutterbaugh J, Park K, Bang YJ, Lee HY, Park JG, Lynch HT, Roberts AB, Vogelstein B and Markowitz SD (1995) A transforming growth factor beta receptor type II gene mutation common in colon and gastric but rare in endometrial cancers with microsatellite instability. Cancer Res 55: 5545-5547

Nakamura S, Ueki T, Yao T, Ueyama T and Tsuneyoshi M (1994) Epstein-Barr virus in gastric carcinoma with lymphoid stroma. Special reference to its detection by the polymerase chain reaction and in situ hybridization in 99 tumors, including a morphologic analysis. Cancer 73: 2239-2249

Nicolaides NC, Papadopoulos N, Liu B, Wei YF, Carter KC, Ruben SM, Rosen CA, Haseltine WA, Fleischmann RD, Fraser CM, Adams MD, Venter JC, Dunlop MG, Hamilton SR, Petersen GM, De La Chapelle A, Vogelstein B and Kinzler KW (1994) Mutations of two PMS homologues in hereditary nonpolyposis colon cancer. Nature 371: 75-80

Ohue M, Tomita N, Monden T, Miyoshi Y, Ohnishi T, Izawa H, Kawabata Y, Sasaki M, Sekimoto M, Nishisho I, Shiozaki H and Monden M (1996) Mutations of the transforming growth factor beta type II receptor gene and microsatellite instability in gastric cancer. Int J Cancer 68: 203-206

Ott G, Kirchner T and Muller Hermelink HK (1994) Monoclonal Epstein-Barr virus genomes but lack of EBV-related protein expression in different types of gastric carcinoma. Histopathology 25: 323-329

Ottini L, Palli D, Falchetti M, D'Amico C, Amorosi A, Saieva C, Calzolari A, Cimoli F, Tatarelli C, Marchis LD, Masala G, Mariani-Costantini R and Cama A (1997) Microsatellite instability in gastric cancer is associated with tumor location and family history in a high-risk population from Tuscany. Cancer Res 57: 4523-4529

Ouyang H, Shiwaku HO, Hagiwara H, Miura K, Abe T, Kato Y, Ohtani H, Shiba K, Souza RF, Meltzer SJ and Horii A (1997) The insulin-like growth factor II receptor gene is mutated in genetically unstable cancers of the endometrium, stomach, and colorectum. Cancer Res 57: 1851-1854

Papadopoulos N, Nicolaides NC, Wei YF, Ruben SM, Carter KC, Rosen C, Haseltine WA, Fleischmann RD, Fraser CM, Adams MD, Venter JC, Hamilton SR, Petersen GM, Watson P, Lynch HT, Peltomaki P, Mecklin JP, De La Chapelle A, Kinzler KW and Vogelstein B (1994) Mutation of a mutL homolog in hereditary colon cancer. Science 263: 1625-1629

Parkin DM, Pisani P and Ferlay J (1993) Estimates of the worldwide incidence of eighteen major cancers in 1985. Int J Cancer 54: 594-606

Parsons R, Myeroff LL, Liu B, Willson JK, Markowitz SD, Kinzler KW and Vogelstein B (1995) Microsatellite instability and mutations of the transforming growth factor beta type II receptor gene in colorectal cancer. Cancer Res 55: 5548-5550

Pisani P, Parkin DM and Ferlay J (1993) Estimates of the worldwide mortality from eighteen major cancers in 1985. Implications for prevention and projections of future burden. Int J Cancer 55: 891-903

Rampino N, Yamamoto H, Ionov Y, Li Y, Sawai H, Reed JC and Perucho M (1997) Somatic frameshift mutations in the BAX gene in colon cancers of the microsatellite mutator phenotype. Science 275: 967-969

Renault B, Calistri D, Buonsanti G, Nanni O, Amadori D and Ranzani GN (1996) Microsatellite instability and mutations of p53 and TGF-beta RII genes in gastric cancer. Hum Genet 98: 601-607

Rhyu MG, Park WS and Meltzer SJ (1994) Microsatellite instability occurs frequently in human gastric carcinoma. Oncogene 9: 29-32

Ruschoff J, Dietmaier W, Luttges J, Seitz G, Bocker T, Zirngibl H, Schlegel J, Schackert HK, Jauch KW and Hofstaedter F (1997) Poorly differentiated colonic adenocarcinoma, medullary type: clinical, phenotypic, and molecular characteristics. Am J Pathol 150: 1815-1825 
Schalling M, Ekman M, Kaaya EE, Linde A and Biberfeld P (1995) A role for a new herpes virus (KSHV) in different forms of Kaposi's sarcoma. Nature Med $\mathbf{1}$ : 707-708

Shibata D and Weiss LM (1992) Epstein-Barr virus-associated gastric adenocarcinoma. Am J Pathol 140: 769-774

Shibata D, Weiss LM, Hernandez AM, Nathwani BN, Bernstein L and Levine AM (1993) Epstein-Barr virus-associated non-Hodgkin's lymphoma in patients infected with the human immunodeficiency virus. Blood 81: 2102-2109

Souza RF, Appel R, Yin J, Wang S, Smolinski KN, Abraham JM, Zou TT, Shi YQ, Lei J, Cottrell J, Cymes K, Biden K, Simms L, Leggett B, Lynch PM, Frazier M, Powell SM, Harpaz N, Sugimura H, Young J and Meltzer SJ (1996) Microsatellite instability in the insulin-like growth factor II receptor gene in gastrointestinal tumours. Nature Genet 14: 255-257

Strickler JG, Zheng J, Shu Q, Burgart LJ, Alberts SR and Shibata D (1994) p53 mutations and microsatellite instability in sporadic gastric cancer: when guardians fail. Cancer Res 54: 4750-4755
Tokunaga M, Uemura Y, Tokudome T, Ishidate T, Masuda H, Okazaki E, Kaneko K, Naoe S, Ito M, Okamura A, Shimada A, Sato E and Land CE (1993) Epstein-Barr virus related gastric cancer in Japan: a molecular pathoepidemiological study. Acta Pathol Jpn 43: 574-581

Watanabe H, Enjoji M and Imai T (1976) Gastric carcinoma with lymphoid stroma Its morphologic characteristics and prognostic correlations. Cancer 38: 232-243

Wojtowicz Praga S (1997) Reversal of tumor-induced immunosuppression: a new approach to cancer therapy. J Immunother 20: 165-177

Yamamoto H, Sawai H and Perucho M (1997) Frameshift somatic mutations in gastrointestinal cancer of the microsatellite mutator phenotype. Cancer Res $\mathbf{5 7}$ $4420-4426$

Yuen ST, Chung LP, Leung SY, Luk IS, Chan SY and Ho J (1994) In situ detection of Epstein-Barr virus in gastric and colorectal adenocarcinomas. Am J Surg Pathol 18: 1158-1163 